\title{
The Ottoman Empire as Friend and Foe: Perceptions of Ottoman Rule in Serbia and Bosnia and Thereupon Based Nationalisms
}

\author{
SRĐAN M. JOVANOVIĆ \\ Sehir University Istanbul, Turkey
}

\begin{abstract}
The Ottoman rule over the Balkans has a long history of diverging perceptions in Bosnia and Serbia. In Serbia, this perception is a predominantly negative one, commonly disseminated 'nation-wide' in history textbooks as '500 years under the Turkish yoke', denoting also a failure to discern the difference between the modern Turkish state and the Ottoman Empire. They are commonly seen as one, both within academia and lay discourse. During the wars of the Yugoslav secession and afterwards, this perception increased in intensity with the counterperception found in Bosnia, where both Turkey and the Ottoman Empire are held in high regard among the Muslim population. A specific type of linguistic nationalism ensued in Bosnia, trying to linguistically connect the native language to Turkish and the state to Turkey, while at the same moment exacerbating the already active Serbian nationalism that found strength in perpetualising the Ottoman Empire as an enemy. This article explores the intertwined nationalisms of Serbia and Bosnia, their high connectedness to the Ottoman Empire, and their interactions, where one sees Turkey as an ally, and the other as an enemy.
\end{abstract}

\section{Introduction}

There is a solid quantity of scholarly production on the Ottoman Empire, including its rule over the Balkans, including perspectives of history, politics, gender, and many more (Anscombe 2006; Buturovic and Schick 2007; Hickok 2006; Mažuranić 2007) as well as a significant amount of works concentrating on Bosnian and Serbian nationalism, especially in the nineties, from and after the wars of Yugoslav secession (Blackburn 1993; Davis 2014; Gow 1994; Kostovicova 2004; Naumović 1999; Rabrenovic 1997; Rieff 1996). Nationalism per se has been extensively studied during the 20th century (Anderson 2006; Billig 1995; Calhoun 1993; Gellner and Breuilly 2008; Kedourie 1961; Ozkirimli 2005; Smith 1983). What this article will concentrate on is a broader, parallel view of Serbian and Bosniak nationalism, primarily in its connection to the Ottoman Empire and today's Turkey, via a content analysis approach to some of the more important discourses in relation to the two countries' relationships and views of the Ottoman Empire and Turkey.

Mustafa Soykut wrote in 2001 how the stereotypical views of the Ottoman Empire and its state-progeny, Turkey, were perpetrated by Europe almost exclusively in a negative manner. He wrote how for protestants, they represented the 'rottenness' of the Catholic; for Catholics - the 'heresy' of the Protestants. For Greeks, Turks were seen as ancient enemies, compared to the Persia of old; for Venice - the ineluctable 'infidel' trading partner, and so on (Soykut 2001: 5). In 1925, the famous lawyer and historian from Serbia, 
Slobodan Jovanović, wrote about the 'oppressed nationalities' under Ottoman rule (Jovanović 1925: 384). Going beyond the Ottoman Balkans, even as far into the twentieth century as 1965, we find a discourse that mentions "dealing with the Ottoman menace" (Schwoebel 1965: 164), and many more. Božidar Jezernik, however, in his 2010 edited volume on the 'Imaginary Turk', claimed how Soykut's aforementioned characterisation was, verbatim, "of course, wrong" (Jezernik 2010: 11). Similar to today's Turkey, the Ottoman Empire had had "many different faces in the eyes of the Westerners, never only one" (Jezernik 2010: 11). Europeans admired it when it was on the peak of its power, whilst dubbing it the "sick man of Europe" (Kedourie 1968: 19) when it went into decline. That Europe used to 'otherise' the East (the Ottoman Empire included), is a fairly well-studied phenomenon (Said 1979). Yet the perceptions of the 'Turk' were various, even though the prevalence of them were, indeed, of a negative pathos. An $18^{\text {th }}$ century instance tells us a lot, when Augerius Gislenius, the envoy of King Ferdinand II to the Porte (1554-1562), wrote how the Ottoman Empire was "powerful and strong", how it had an "excellent army, experience in warfare ... order and discipline" (Gislenius 1744: 137). In short, representations of the Ottoman Empire were multifaceted, though often seen through the lens of Orientalism. To paraphrase (Shotwell 1949: 15), the largest of all iron curtains in history is the one that separated - and still separates - the Muslim world from the Christian.

This is an important moment for the analysis and presentation of the 'perception of the Turk' in Bosnia and Serbia (or, to be more precise, by Bosniaks and Serbs), and how these perceptions played a role in the development of their respective nationalisms. Namely, the discursive hatred against the Turkish Other among Serbs in Serbia and Bosnia is often seen as intrinsic to Serbian nationalism, which was seen more often than not both prior to and during the Balkan wars in 1912-13, as well as during the wars of the Yugoslav secession in the 1990s. The general of the Serb army during the wars of the Yugoslav breakup, the Hague inductee Ratko Mladić, for instance, spoke in 1995 (after the taking over of Srebrenica and a subsequent genocide of the local Muslim population) that the time had come to "take vengeance against the Turks" in the area around Srebrenica (Šuica 2010: 287). On the other hand, Bosniaks have by the end of the twentieth century started to increasingly see Turkey as a sort of a 'big brother', a patron state, stemming from the view exemplified by Vasa Čubrilović whilst claiming that "they [Bosniaks] are something special in the Muslim community in the Ottoman Empire" (CK-SK-BiH 1968). However, while the Serbian view of the Ottoman Empire and Turkey can be seen as singularly negative, the Bosniak view did vary prior to the wars of the nineties, as nationalist tendencies initially viewed Turkey as an exploitative factor. Avdo Humo claimed that "it was probable that in a different situation, if Bosnia had been freed from Turkish 
occupation earlier, the process of forming of the Bosnian nation could have started" (CK SK BiH 1968). Even though Humo, at the 17th convention of the Communist Party in Bosnia and Herzegovina clearly saw the Ottomans as a "foreign exploiter in Bosnia and Herzegovina" (Lučić 2009: 112), the rest of the caucus claimed otherwise, stating that "when it comes to the Turkish occupation of Bosnia and Herzegovina, things are always seen in black and white ... All historical documents, which speak differently about the Turkish occupation, claim otherwise" (Lučić 2009: 112). More often than not, nonetheless, the Ottoman Empire and Turkey have mostly been seen in a positive light in Bosnia, especially from the wars of the 1990s, and it is towards the Turkish language that Bosniak linguistic nationalists have turned whilst constructing their national identity, which will be clarified in the pages to come.

Assessing the impact of the Ottoman Empire and Turkey in the development of Serb and Bosniak nationalism is arguably best seen through discourse. To quote Van Dijk, "the way we approach these questions and dimensions is by focusing on the role of discourse in the (re)production and challenge of dominance" (van Dijk 1993: 249); after all, nationalism has always had dominance of one social group - one nation - as a crucial building block. Ultimately, "nationalism is seen as a discourse constructed in social relations" (Hall 1998). Whichever time period we choose to settle on, provided primary sources are aplenty (which, in this case, they are), "the broad categories of "political language' or 'discourse' have proven useful as analytical tools for many periods" (Müller 2011: 583), to use Jan-Werner Muller's words. We need to have in mind that "the discourse of nationalism shows that the material/spiritual distinction was condensed into an analogous, but ideologically far more powerful, dichotomy: that between the outer and the inner", between friends and enemies (Moaddel 2005: 624). This article intends to delve into the discursive creation of 'the Turk' as an enemy (in the Serbian case) and as a friend (in the Bosnian case).

\section{Against the Turkish 'Other' - the Serb case}

The development of Serbian nationalism traces its roots back to the formation of the nation during the 19th century, and it is heavily connected to the two Serbian uprisings against the Ottoman rule during the century. In Sundhaussen's words, "with the First and Second Serb Uprising in 1804 and 1815 against the rule of the Ottomans, the beginning of the Serbian state and nation commences" (Sundhaussen 2008: 31). It is well known in the study of nationalism that the formation of a national identity is not only about "what one is", but also "what one is not", that a strong common enemy is almost a necessity for the formation of the nation (Billig 1995; Delanty 2006; Haldrup et al. 2006), and the role of the enemy was discursively taken by Turkey and the Ottoman Empire. Though nationalism gradually developed during the 
19th century, Serbian nationalism claimed the distant past as the mythical source of today's problems. One key moment can be identified with more ease: the 1389 Battle of Kosovo, which "takes the key role in the collective memory of Serbia" (Sundhaussen 2008: 38), the battle in which the local Christian populations of the Balkans (from the regions of today's Bosnia, Serbia, Albania and Bulgaria) unsuccessfully confronted the invading Ottoman Empire. This battle became the basis of an ongoing myth of Serbian nationalism, one that "rests on the foundation and aesthetisation of that which never happened. The Battle of Kosovo was not the 'fateful crossroads' or 'largest disaster' in Serbian history" (Sundhaussen 2008: 125), yet it was presented as such, and the fight against the "Turkish oppressors", stemming from the "fateful" clash on the field of Kosovo in 1389, became the basis of Serbian nationalism, as "through chronicles, notes and oral tradition the legend gradually evolved, over time greatly exceeded the significance of the battle and its consequences and spread throughout the territories populated by Serbs, and even among some neighbouring nations" (Trgovcevic 1999). The Kosovo trope became the foundation of an anti-Turkish nationalism, pegging the blame onto Turks since the $14^{\text {th }}$ century onwards for a vast array of historical and political instances seen as negative in a nationalist light. The reverberations of the Kosovo-based anti-Turkish Serbian nationalism have endured throughout the 20th century, from the Balkan wars to the wars of the Yugoslav secession, and even today, in the 21st century, in the discourse of nationally oriented parties and politicians. The Kosovo trope was - and is all permeating:

I woke up early, but I did not want to go downtown. The first thing I thought about was that today is St. Vitus Day. In my thoughts I was more in Kosovo than in my room. It made me sad. I could do almost nothing (Mišković 2011).

The words above were written "around 1850 by a young Serb during his studies at a Western university ... In his fantasies, he was transported back to the fourteenth century, and took part in the famous battle of Kosovo on St. Vitus Day, 28 June 1389" (Mišković 2011). Similar instances are copious. After the Balkan wars of 1912-13, the words of a Serbian soldier were recorded:

The single sound of that word - Kosovo - caused indescribable excitement. This one word pointed to the black past - five centuries. ... My God, what awaited us! To see a liberated Kosovo. ... The spirits of Lazar, Milos, and all the Kosovo martyrs gaze upon us. We feel strong and proud, for we are the generation which will realise the centuries-old dream of the nation (Emmert 1990).

The Ottoman rule is often presented as the 'five hundred years of Turkish yoke'. The Illustrated War Chronicle, which started coming out in 1912 on the eve of the Balkan wars, where Serbia, together with the other Ottoman vassals-cum-nations in the Balkans rose up against the Ottoman Empire, reported in the following fashion: 
There has been suffering for five centuries. There has been torture for five hundred years. It had been a sea of suffering. The whole nation lived in agony. The Serbian nation. Turks tortured it, for the Serbian nation slaved under the Turks. Even those who were out of the reach of the Turkish government suffered. We all know it, because we suffered. For whilst we were still suckling on the mother's breast, they sang to us songs of Kosovo and slavery. Then we were told stories about slavery and suffering. When we learned to read, we read folk poetry, we read them to ourselves and to others, and the feelings of suffering and longing for vengeance crept into our soul. All our national soul filled with bile (IRK 1912).

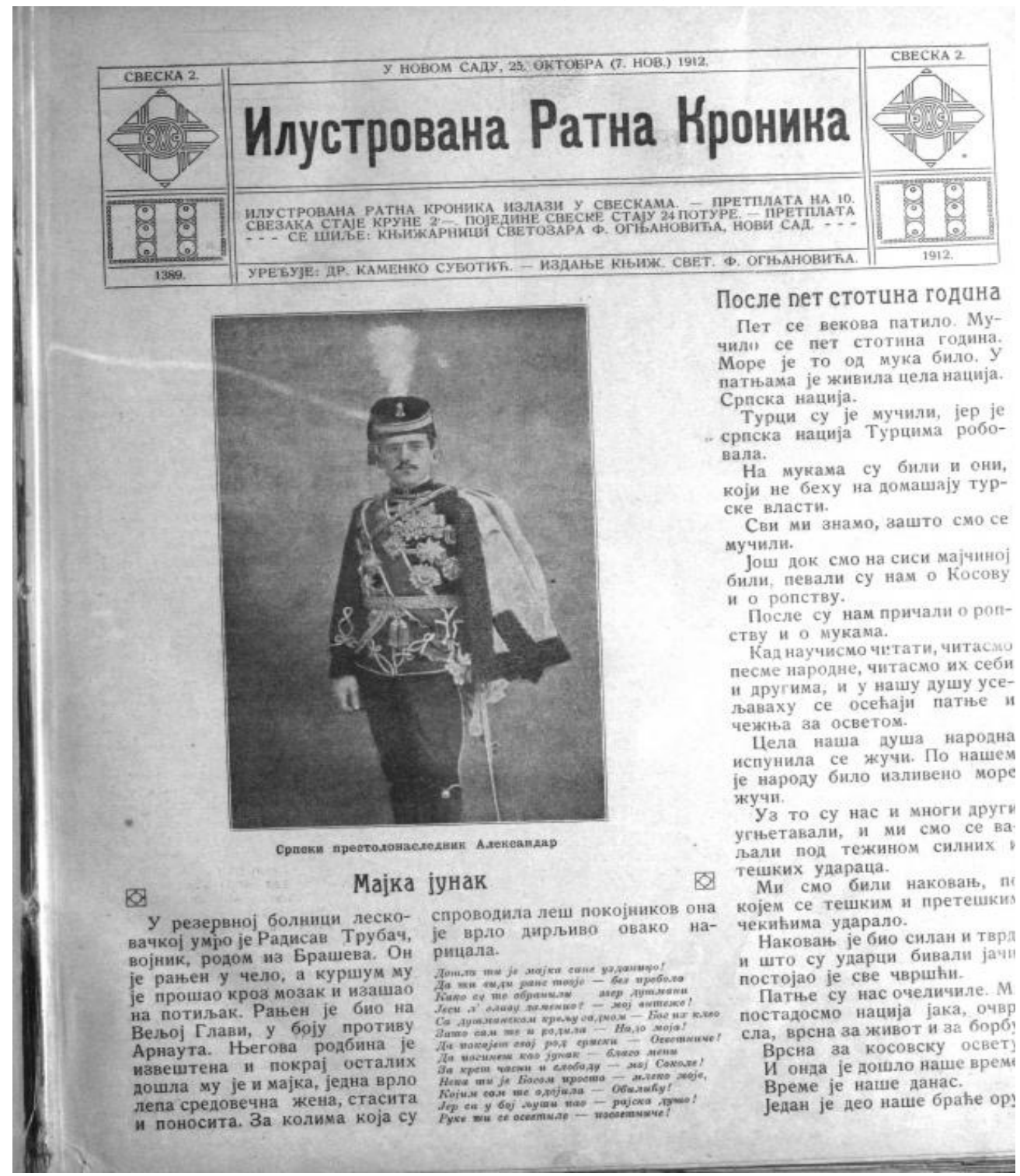

Image 1: The Illustrated war chronicle, 25 October 2015, with the text about "suffering under the Turkish yoke" in its original form. Source: National Library of Serbia, Belgrade. 
The "mythical aura of the Turkish yoke" (Ignjatović 2012: 527) and the suffering against the Turks was as present by the beginning of the 20th century, as it was at its end. It was often written that "Belgrade itself fell once more under the Turkish yoke" (Stajić 1926: 106), stressing "the suffering endured by the Christian Slavic population during the long night of Turkish rule in the Balkans" (Matthias and Vučković 1987: 14) time and again. The Ottoman rule was presented as centuries of anguish, misfortune and hardship, as it was necessary to justify the upcoming war against the Empire. The discursive method by which this is accomplished is the presentation of uncorroborated stories, ripe with a warmongering pathos. Such a discourse was not present only in the media, nonetheless, as it is not overly tasking to find 'reports' of 'Turkish backwardness' in official writings of late nineteenth century politicians, such as Stojan Novaković, the president of the Ministerial Council of Serbia in 1895-6, who wrote that "in some backwater parts of Turkey ... the Middle Ages still live in a ripe fashion" (Novaković 1886: 17). These gentle 'reminders' of the Turkish alleged primordial nature were a discursive introduction to the much more potent warmongering discourse of 1912.

In 1912, this anti-Turkish nationalism was ripe. After the defeat in the war that the Ottoman Empire waged in Libya, with its armies weakened, the fledgling Balkan nations saw an opportunity to strike (Pavlovič 1999). Montenegro declared war against the Empire, very soon to be followed by Serbia, Greece and Bulgaria, who all saw an opportunity for geopolitical acquisition. In order to prepare the population for the upcoming war, the discursive mobilisation against the Ottoman Empire in Serbia became pregnant with nationalism, fuelled almost exclusively by anti-Ottoman sentiment. The media from 1912 present a rather clear picture, as the War Chronicle published calls for war, epic poems and an almost unsolicited hatred against the Turkish 'Other'. Kosovo, simply, had to be 'liberated' by the Turks. The Illustrated War Chronicle published a poem on 31 October 1912:

Serbs, brothers, chosen heroes!

The days of want have already come

To seek for what once was Serbian

To avenge the tzar and Kosovo!

It is the wish of every Serb,

To retake the tzardom of Dušan! 


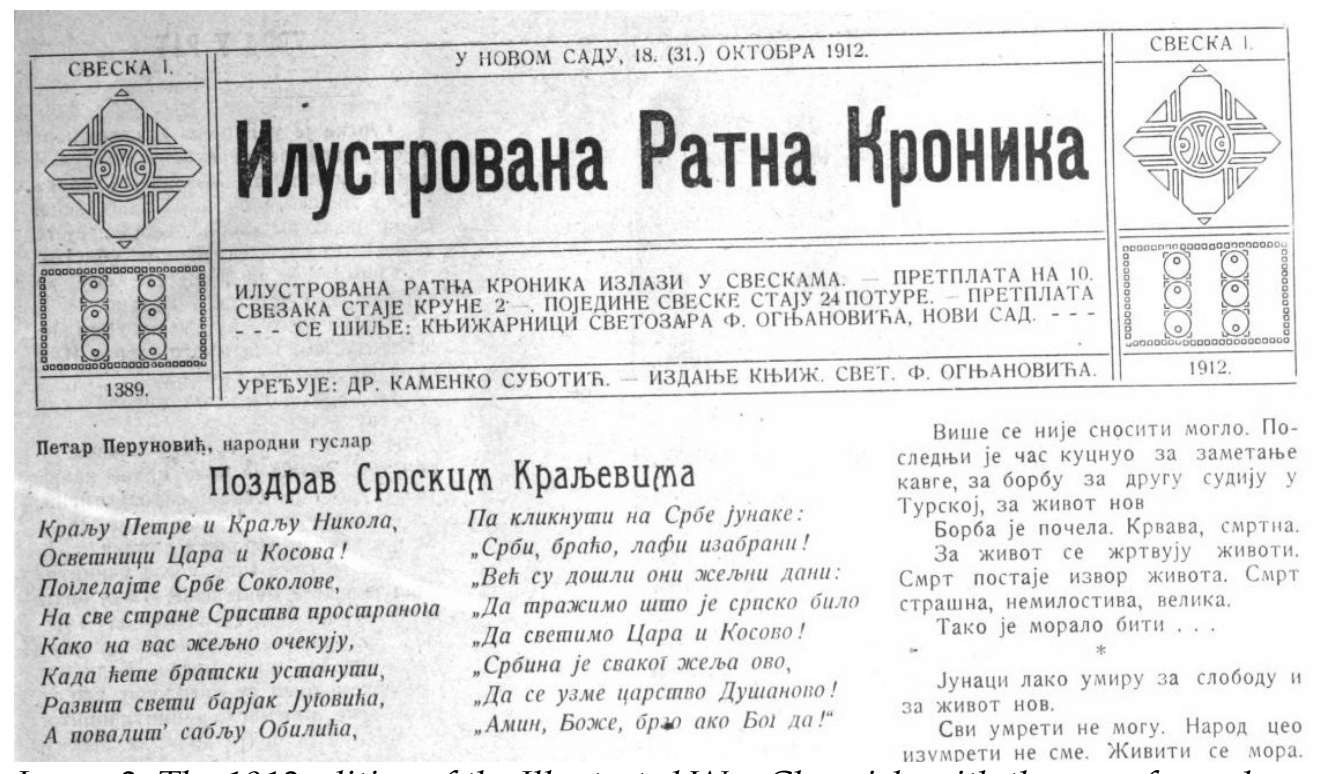

Image 2: The 1912 edition of the Illustrated War Chronicle with the song from above in its original form. Source: National Library of Serbia, Belgrade.

Kosovo was the "grave of an old Serbian freedom; that is Kosovo, the realisation of the new Serbian freedom since 1912, Kosovo whose earth soldiers used to kiss and carry back home in bags, to show to their wives and children." (Trgovcevic 1999). This Kosovo needed to specifically be 'freed' from 'Turkish occupation', a trope that will have its day de novo by the end of the twentieth century, reaching its denouement.

\section{Serb nationalism in the 1990s and the Turk enemy}

The Yugoslav wars of the 1990s saw a rehash of Serb nationalism based on anti-Turkish feelings and discourses. Ratko Mladićs exact words after the invasion of Srebrenica were the following: "Here we are in Srebrenica on July 11,1995 . On the eve of yet another great Serb holiday. We present this city to the Serbian people as a gift. Finally, the time has come to take revenge on the Turks" (Stover and Peress 1998: 88-89). The Bosniak Muslim population was, and is often seen in such a discourse, as 'Turkish', as "the Serb army would invade Bosnia and turn its weapons against the imagined 'Turks' with a violence not seen in Europe in fifty years", with the press reporting "headlines as 'Crime Like in the Time of Turks"' (Boose 2002: 879). Some researchers even claim that "I'll be first, who'll be second to drink some Turkish blood?" became a slogan in Serbia (Cigar 1996: 57). The Muslim became discursively synonymous with the Turk, and reports have shown a grisly picture of a bloody war:

In an orgy of nationalism bathed in alcohol, athletic contests, and Serbian songs, Serb soldiers threw Muslims off cliffs and from hotel roofs into rivers, carved Orthodox 
crosses into their chests, hacked off the arms or legs of their victims, made women clean up the mess from such amputations, and then raped the women on top of the blood-soaked rags (Boose 2002).

Destroying the Muslim Other became a prerogative and imperative. Killing a Muslim - a 'Turk"' - became a heroic deed, reminiscing of the 'golden ages' of the Serbian state from six hundred years ago.

According to frequently echoed testimony from female survivors, as the usually drunken, enraged soldiers raped and beat them, the rapists screamed either "Turkish whore" or "Ustashe whore" at their victims, triumphantly jeering after reaching orgasm that the woman was now carrying "Serb seed" and would produce a "Serb baby" (Boose 2002: 75).

The hatred towards the Turk used to be transferred even unto the Albanians of Kosovo (which warred against Serbia whilst still officially an autonomous province within the country) were seen as Turks; "while it seems clear that the Albanian Kosovars are neither Turks nor Slavic converts guilty of race betrayal, within the Serb vocabulary the mostly Muslim Albanian majority in Kosovo (or Kosovars) can become 'Turks' almost as readily as can the Bosnian Muslims" (Boose 2002: 77). Ježernik's 'imaginary Turk' became the enemy once again. That the image of the Turkish enemy was extraordinarily potent can be seen in the development of the nationalist discourse after 1878, for which Pavlović (2015:17) states that at that time, the figure of the Albanian muslim becomes the 'torturer of remaining Kosovo Serbs' as a 'Turkish ally'.

\section{Bosnia: Love for the Turkish brother}

Whilst we can follow the development of Serbian nationalism from the 19th century onward and the formation of the Serbian nation (although its nationalists would claim that their nation has existed since primordial times and from what Sundhaussen dubbed the myth of the 'golden age' of the Serbian medieval state), Bosniak nationalism can be said to have started developing from the late sixties, during the age of the Socialist Federate Republic of Yugoslavia, with the creation of the 'Muslim' national identity, that will develop into what is today known as 'Bosniak' during the 1990s (Greenberg 2004: 136). This particular national identity is somewhat specific by two facts: one is that it is the youngest, most recent national identity produced by former Yugoslavia (having in mind that the newest independent state, Kosovo, mostly boasts an Albanian national identity), the second being that it is the only European national identity that stemmed specifically from a religion, in this case, Islam.

The particularity at hand lies in the fact that the initial designation for today's Bosniaks was 'Muslim', with a capital " $\mathrm{M}$ ". This was to stand in opposition to 'muslim', low-cased in Serbo-Croatian, which denoted the religion, while 'Muslim' denoted the nation (the problem with discourse in English is that 
religious denominations are written in large caps a priori). Having in mind that the Muslim ('muslim') religion was the one and most important starting point for the development of the nation, it is of small wonder for the newly formed Bosniak nation to often call upon Turkey for support. Even after the wars of the Yugoslav breakup, as noticed by Petrović and Reljić,

Turkish involvement in Bosnia and Herzegovina's affairs is a contentious point in that divided country. While most Bosniaks see the Turkish presence as guaranteeing their interests in a future unified state, Bosnian Serbs see it as an obstacle to the preservation of the Dayton-Paris system, which they so unyieldingly defend (Petrović and Reljić 2011).

This was of small wonder, having in mind that "the rise of nationalism among the Balkan Christians produced devastating results for the Muslims (and the Jews) on the peninsula" (Cagaptay 2006: 6); concentrating on the religious affiliation for the Bosniak nation was, essentially, the only way to go. It would be wise to note at this point that during the wars of the nineties, religious affiliations on all three warring sides (Croatia, Bosnia and Serbia), religion played a key role in strengthening national identities - a Croat had to be Catholic, a Serb - Orthodox, while a Bosniak needed to be Muslim. The only difference of importance was that the Bosniak national identity did not have many other instances to resort to.

Even today, there is a strong connection between Bosnia and Turkey. The then foreign Minister Davutoğlu

has paid special attention to explaining the rationale for the new Turkish vigor in the
region. In a landmark address in Sarajevo on October 16, 2009, on the occasion of the
opening ceremony of the 'Ottoman legacy and Balkan Muslim Communities Today'
conference, Davutoğlu spoke about the Balkans as a 'geo-political buffer zone', which
overcame this position to become the centre of world politics during Ottoman rule in
the 16th century. He promised that Turkey would 'reinvent' and 're-establish' this
'golden age of the Balkans'". (Petrović and Reljić 2011: 161-62)

The mention of the Ottoman empire and its history became prominent in the Bosnia-Turkey discourse: "We are paying the bill for our Ottoman history because whenever there is a crisis in the Balkans (Bosnians, Albanians, Turks in Bulgaria...) they look to Istanbul" (SETA.dc 2009). In short, "in Bosnia and Herzegovina, in comparison to the rest of the region, Turkey has managed to achieve its greatest political and cultural influence" (Petrović and Reljić 2011: 168).

Turkish influence in Bosnia continues to be potent on many levels even today. "Turkey is also building schools and universities in those parts where they are likely to be appreciated, for example in areas with a predominantly Muslim population" (Petrović and Reljić 2011: 166), and Bosnia is exactly the main location for such an endeavour. Similarly, the mention of the 
designation 'Balkan' evokes the image of Bosnia among many contemporary Turks (students included, who more often than not go to Sarajevo for study visits).

Recep Tayyip Erdogan himself has developed a relationship with Bosnia during the 2010s, when he in 2013 said, during a visit to Kosovo, that "Kosovo is Turkey, and Turkey is Kosovo", evoking ovations from Bosniak nationalists, while in 2012, he even went that far as to claim that "Alija Izetbegović left Bosnia to him as a testament" (Info-ks 2016).

\section{The 1990s: Bosniak linguistic nationalism}

With the development of Bosniak nationalism, its Serbian and Croatian counterparts were slightly 'ahead', and they have already developed a Herderian type of linguistic nationalism (after the ethnic and religious instances were 'set straight'). Nationally minded linguists in both Serbia and Croatia decided to 'split' the Serbo-Croatian language into Serbian and Croatian. We need to have in mind that the alleged differences between the newly formed Serbian and Croatian were minimal, even below the level of dialects in linguistics. To quote Gröschel, the languages spoken by Croats, Serbs, Bosnians and Montenegrins were "variants of a single polycentric language" (Gröschel 2003: 183). What is more, these differences are, linguistically, smaller than the differences between standardised varieties of German (Gröschel 2003: 180-81), Spanish (Thomas 2003: 314) or even English (Pohl 1996: 219). In the words of Snježana Kordić, "for Slavistics, as a discipline within systemic linguistics, there is no reason to start classifying Serbian, Croatian, Bosnian (and Montenegrin) as separate languages" (Kordić 2001: 238). Yet these minor differences were blown out of proportions where they did exist, and invented where they did not, all in order to try to present Serbian and Croatian as separate languages.

Bosniak linguistic nationalism was late to the fray, having the language already 'split' between the warring sides of Serbia and Croatia. A heavy stretch needed to take place in order to create a Bosniak language out of nothing; as Greenberg wrote, "the task of establishing a new Bosnian language has been particularly arduous" (Greenberg 2004: 136), and the 'solution' came from the Bosniak orientation towards Turkey and the Turkish language.

Bosniak linguistic nationalism was the least factually based instance in the Bosniak nationalist development of the nineties. As Greenberg wrote, "while Slavic standard languages, such as Czech, Slovene, or Polish developed over several centuries, the Bosnian language erupted suddenly and unexpectedly in the context of the 1992-5 war in Bosnia-Herzegovina. The birth of a new Bosniac identity coincided with the proclamation of the language in 1992" 
(Greenberg 2004: 136). The language was already artificially split into two, with some authors claiming how numerous linguistic instances differ between Serbian and Croatian. The nationally minded Croat linguists Kačić and Šarić, for instance, went so far even to claim that there are differences on the level of literary language, on the level of the standard language, and even on the level of typology, as they claimed that "differences exist on all levels of the linguistic system: phonetic/phonological, accentual, morphologic, word-formational, syntactic, semantic-pragmatic and lexical. Linguistic systems which differ on all these levels cannot be one language" (Kačić and Šarić 1997). Finding something to make it typically 'Bosniak' was a daunting task, and the solution was found primarily in what was a local perception of the influence of the Turkish language, as the dialectological materials from Bosnia-Herzegovina suggested that two linguistic features have pervaded the speech of the Bosniaks, as opposed to their Serb and Croat neighbours. These most salient of these features included: (1) the greater frequency of the velarfricative $h$, and (2) the greater number of Turkish/Arabic loanwords (Greenberg 2004: 145).

Serbo-Croatian, namely, boasts over 8500 lexemes stemming directly from Ottoman Turkish (some of them came to Turkish from Persian and Arabic a long time before they came to the Balkans), and the core of the Bosniak linguistic nationalism was to present these words of Turkish linguistic historical origin as intrinsically 'Bosniak'. These include a plethora of mispronounced Turkish words, such as 'amca' /am'dsa/, pronounced /'amidsa/, or 'hekim' (pronounced /'xe:kim/ instead of /he'kim/). Out of those, one phonetic instance started to be seen as intrinsically Bosnian, namely the phoneme / $x$ / (such as the ' $h$ ' in Ser-Cro 'hleb' or 'hvala'. Note that the Turkish grapheme ' $h$ ' represents a different phoneme altogether, pronounced $/ \mathrm{h} /$, as a puff of aspiration, whilst $/ \mathrm{x} /$ in Serbo-Croatian is a velar fricative). This included mispronouncing words such as the Turkish greeting 'merhaba' (Tur. / mera'ba/) pronounced with a strong stress on the originally non-Turkish / $\mathrm{x} /:$ /mer'xa:ba/. A similar misperception can be seen in the pronunciation of the word 'sat' / sa:t/ (hour), which became 'sahat' / saxat/, even though the Turksih word for 'hour' is 'saat' / sa:t/, and that $/ \mathrm{x} /$ does not even exist in Modern Turkish. As Greenberg wrote in detail:

The new Bosnian grammars and dictionaries now admit such forms as: (i) lahko "easy", mehko "softly", where h is etymologically justified; (2) hudovica "widow", hlopta "ball", where h is not justified etymologically; and (3) sahat "hour", halat "tool", havaz "voice" $\mathrm{h}$ is found or added in words of Turkish origin. In this manner, the Bosnian language could boast forms different from the corresponding Serbian and Croatian forms, e.g., lako, meko, udovica, lopta, sat (Greenberg 2004: 145).

According to Greenberg (2004:137), "the codifiers of the new language have argued that a separate Bosnian language was evolving since the Ottoman 
occupation", yet this was a gamut in need of severe stretching. To go into more details, in Greenberg's words, there were no grammars or handbooks for the Bosnian language until 1890, when the Austro-Hungarian administrator Benjamin Kallay sought to counteract Serbian nationalism in Bosnia-Herzegovina by promoting a Bosnian identity by establishing a Bosnian language. To this end, Frane Vuletić, a high school teacher from Sarajevo, was asked to write a book of Bosnian grammar, which appeared in 1890. Vuletic himself opposed the term 'Bosnian', and had preferred calling the language 'Serbo-Croatian', 'Croato-Serbian', 'Croatian or Serbian', or 'Serbian or Croatian' (Greenberg 2004: 137).

However, when the Austro-Hungarian authorities ended up rejecting these names, the new grammar went under the name of the "Grammar of the Bosnian language" (Curtis 2001: 64), showing that the very first instance of 'officialdom' for the Bosnian language started the same way a bit over a century before the 1990s - in a political fashion. This called for a series of declarative discursive statements from the proponents of the fledgling linguonim, and so the nationally-minded Bosniak linguist Jahić proclaimed, verbatim, that " $\mathrm{t}$ ]he Bosnian language (as was demonstrated during Kallay's times) is not a political invention, but a significant cultural current, which has followed Bosnia through history", (Jahić 1999: 29) with no evidence to back up his claims. The 1890 grammar was used as a way to stress the continuity of the Bosniak language, even though the very grammar itself boasted none of the newly invented 'bosniakisms' of the 1990s (Vuletic 1890). The farce went so far that in 1998 a "Sympozium on the Bosnian language" was held in Sarajevo, where the fiercest proponents of Bosnian as a separate language, Senahid Halilović and Dževad Jahić, "displayed nationalist credentials. Jahić's statements were reminiscent of Herderian concepts on the powerful link between language and national/cultural identity" (Greenberg 2004: 151). Jahić even admitted his nationalist tendencies, saying how

[i]nsofar as language is a means of communication, it is also an aspect of national identification. In it are the whole culture, history, and consciousness of a given people ... [or] better put, collective subconsciousness about its past, its present, and perhaps even its future. (Jahić 1999: 25)

Such a pathos continued well into the 21st century, when promoters of the Bosnian language as a standalone linguistic idiom claimed that the "prolonged continual attacks on the Bosnian language ... are a part of a larger and systematically organised action of denying Bosnia and Herzegovina as a state ... language is a strong component of national identity" (Agić 2016), seldom basing the idea on linguistics, but instead continuously choosing national identity and etatism as the foundation for the existence of a separate Bosnian language. Another problem stems from the fact that among those who deny the existence of a separate Bosnian language (mostly nationally 
oriented Serbs from the Republika Srpska and Serbia), rarely to never claim so on the basis of linguistics as well, but also on the basis of anti-Bosnian (and anti-Turkish, in a bigger picture) nationalism. This, however, is beyond the scope of this article.

As the time went by, with the continuation of nationalist policies in Croatia, Serbia and Bosnia and the ever-present ethnic divide, all three new language names - including Bosnian/Bosniak - became widely used. From a linguistic perspective, though, this does not negate the fact that all those three names represent a single language. In the meantime, in Greenberg's words, "Bosniac linguists will be under much pressure to continue justifying the need and legitimacy of their separate standard, and some linguists may continue to resist perceived Serb or Croat influences" (Greenberg 2004: 157). Indeed, "in Yugoslavia, the power of language has at times reached absurd proportions" (Greenberg 2004: 159).

\section{Instead of a conclusion}

With the 15 July 2016 unsuccessful coup in Turkey, Recep Tayyip Erdogan managed to successfully strengthen his grip on the country by enacting a state-wide cleanse of any and all remnants of the opposition, from judges, via the military, to the press and the universities. Several thousand people have either lost their jobs, or have been apprehended; by the time of the writing of this article, the numbers kept steadily increasing. Robert Ellis of the Independent even claimed that:

even before the coup, in a process similar to the Nazi party's policy of Gleichschaltung (coordination) the AKP has gradually taken control of all aspects of Turkish society. Like the Third Reich's Sondergerichte (special courts), two years ago a system of penal courts of peace was established, each with a specially appointed single judge to take care of opponents of the regime (Ellis 2016).

The post-coup situation in Turkey - namely the swift and expeditious expurgation of non-Erdogan supporters - escalated to such proportions, that the Economist wrote how:

the purge is so deep and so wide-affecting at least 60,000 people-that some compare it to America's disastrous de-Baathification of Iraq. It goes far beyond the need to preserve the security of the state. Mr Erdogan conflates dissent with treachery; he is staging his own coup against Turkish pluralism. Unrestrained, he will lead his country to more conflict and chaos (Economist 2016).

Reactions were to be felt on a world-wide scale, though a significant amount of support for Erdogan (including his actions after the coup) were to be seen among Bosniak nationalists. AlJazeera Balkans, based in Sarajevo, called the coup "a dark night, but it ushered in light for democracy in Turkey" (Dalay 2016), including that "Turkey now has an opportunity to use the attempted 
coup for national reconciliation". The SAFF portal wrote how Erdogan was a man of "morality and high levels of courage", and that "the Sultan Erdogan should keep arresting" (Jakupi 2016). Sead Nasufović, the recently elected Reis-ul-ulema of the Islamic community in Serbia (the Bosniak minority in Sandžak, western Serbia) claimed how "Erdogan is a great politician, democratically elected, whose values are recognised by the whole world, so I think that he has the knowledge and wisdom, will and support to deal with the temptations that have befallen his country" (Bajrović 2016). This support went so far as to see three different civic organisations in Bosnia (Preporod, Udruženje demokratskih pravnika and BOSFOR) to recommend Erdogan for a Nobel peace prize (Klix.ba 2016). It is impossible to predict how the future impressions and perceptions of Turkey among Bosniaks and Serbs are going to develop, having in mind the tumultuous times facing Turkey. So far, the discourse relating to Turkey stands firmly planted in the murky waters of bias and predilection.

Nationalisms are entities in a flux. In addition, they are, however idiosyncratic it might sound, both flexible and rigid at the same time, depending on the historical, political and social situation, as well as the personal choice of those who are discursively creating it and promulgating it. In the case of the Balkans an generale, the Ottoman Empire played a key role. For the Serb side, it presented a fixed discursive instance, naming the orientalised Turk enemy as the perpetual adversary, while it took a while, with some discursive discrepancies, for Bosniak nationalism to settle with a positive image of Turkey. Nationalism connected to Turkey and the Ottoman Empire had led to some gruesome happenings in recent history (such as the genocide against Muslims in Srebrenica) on the nationalist Serb side, as well as to some bizarre ones (the Bosnian language) on the nationalist Bosnian side, including the support of a more and more authoritarian Turkey. Yet what we continuously need to keep in mind is that all of these instances had been condoned and perpetrated by a nationalist minority on both sides, lest there never be true peace in former Yugoslavia.

\section{References}

Agić, Jasmin (2016) 'Bosanski jezik kao žrtva nevremena', In Al Jazeera Balkans, [19 July 2016] [accessed: 15 September 2016].

Anderson, Benedict (2006) Imagined communities: Reflections on the origin and spread of nationalism. Verso Books.

Anscombe, Frederick (ed.) (2006) The Ottoman Balkans 1750-1830.

Bajrović, Amela (2016), Srbija: podeljene islamske zajednice jedinstvene o Erdoganu', Radio slobodna Evropa, [Online, 30 July 2016]. Available at: 
http://www.slobodnaevropa.org/a/srbija-podeljene-islamske-zajednicepodeljene-o-erdoganu/27872985.html [accessed 15 September 2016].

Billig, Michael (1995) Banal Nationalism. Sage.

Blackburn, Robin (1993) The Break-up of Yugoslavia and the Fate of Bosnia. New Left Review, (199), 100.

Boose, Linda E. (2002) Crossing the River Drina: Bosnian Rape Camps, Turkish Impalement, and Serb Cultural Memory. Signs, Gender and Cultural Memory, 28 (1), 71-96.

Buturovic, Amila and Schick, Irvin Cemil (2007) Women in the Ottoman Balkans: gender, culture and history, 15: IB Tauris.

Cagaptay, Soner (2006) Islam, secularism and nationalism in modern Turkey: Who is a Turk? London: Routledge.

Calhoun, Craig (1993) Nationalism and ethnicity. Annual review of Sociology, 19 (1), 211-39.

Cigar, Norman (1996) The Serbo-Croatian War, 1991. In Stjepan G Meštrović (ed.) Genocide after Emotion: The Postemotional Balkan War. London: Routledge, 51-90.

CK-SK-BiH (1968) Discussion on the 17th Convention of the Central Committee of the Communist Party of Bosnia and Herzegovina.

Curtis, Ford (2001) The (Re-)Birth of Bosnian: Comparative Perspectives on Language Planning in Bosnia-Herzegovina. Ph.D. Dissertation, University of North Carolina at Chapel Hill.

Dalay, Galip (2016) Narod je osujetio vojni udar. In Al Jazeera Balkans, [Online, 20 July 2016]. Available at: http://balkans.aljazeera.net/vijesti/narod-jeosujetio-vojni-udar [accessed 15 September 2016].

Davis, G Scott (2014) Religion and Justice in the War over Bosnia. London: Routledge.

Delanty, Gerard (2006) Nationalism and cosmopolitanism: The paradox of modernity. The SAGE Handbook of Nations and Nationalism. London: Sage, 357368.

The Economist (2016) Erdogan's revenge. In The Economist [Online, 20 July 2016]. Available at: http://www.economist.com/news/leaders/21702465turkeys-president-destroying-democracy-turks-risked-their-lives-defenderdogans [accessed 15 September 2016]. 
Ellis, Robert (2016), Erdogan's 'democratic' mandate has uncomfortable parallels with Europe's past. In The Independent [Online, 25 July 2016]. Available at: http://www.independent.co.uk/voices/president-erdoganturkey-coup-attempt-elected-turkish-state-modelled-third-reicha7150956.html [accessed 14 September 2016].

Emmert, Thomas A. (1990) Serbian Golgotha: Kosovo, 1389. East European Monographs/Columbia University Press.

Gellner, Ernest and Breuilly, John (2008) Nations and nationalism. Cornell University Press.

Gislenius, Augerius (1744) Travels into Turkey: Containing the most accurate Account of the Turks, and Neighbouring Nations, Their Manners, Customs, Religion, Superstition, Policy, Riches, Coins, \& c. London: J. Robinson.

Gow, James (1994) Serbian Nationalism and the Hissssing Ssssnake in the International Order: Whose Sovereignty? Which Nation?, The Slavonic and East European Review, 72(3), 456-76.

Greenberg, Robert D. (2004) Language and Identity in the Balkans. Oxford: Oxford University Press.

Gröschel, Bernhard (2003) Postjugoslavische AmtssprachenregelungenSoziolinguistische Argumente gegen die Einheitlichkeit des Serbokroatischen?, Srpski jezik, 8(1-2), 135-96.

Haldrup, Michael, Koefoed, Lasse, and Simonsen, Kirsten (2006) Practical orientalism-bodies, everyday life and the construction of otherness. Geografiska Annaler: Series B, Human Geography, 88(2), 173-84.

Hall, Patrik (1998) The social construction of nationalism: Sweden as an example. Lund University Press.

Hickok, Michael R (2006) Homicide in Ottoman Bosnia. The Ottoman Balkans, 35-59.

Ignjatović, Aleksandar (2012) Images of the Nation Foreseen: Ivan Meštrović's Vidovdan Temple and Primordial Yugoslavism. The Slavonic and East European Review, 90(3), 527-30.

Info-ks (2016), Erdogan: Kosovo je Turska, Izetbegović mi je Bosnu ostavio u amanet. In Info-ks [Online, 30 July 2016]. Available at: http://www.infoks.net/vijesti/regija/46045/erdogan-kosovo-je-turska-izetbegovic-mi-jebosnu-ostavio-u-amanet

IRK (1912) Posle pet stotina godina. Ilustrovana ratna kronika. 
Jahić, Dževad (1999) Lingvisticki i kulturno-historijski izvori bosanskog jezika: glavna problemska pitanja. Simpozij o bosanskom jeziku (zbornik radova), 25-30.

Jakupi, Arben (2016) Pala je najstarija poznata diktatura! In Bošnjaci.net. Available at: http://www.bosnjaci.net/prilog.php?pid=59486 [accessed 11 September 2016].

Jezernik, Božidar (2010) Uvod. Stereotipizacija 'Turčina'. In Božidar Jezernik (ed.) Imaginarni Turčin. XX Vek, 9-29.

Jovanović, Slobodan (1925) Serbia in the Early Seventies. The Slavonic Review, $4(11), 384-95$.

Kačić, Miro and Šarić, Liljana (1997) Croatian and Serbian: Delusions and distortions. Zagreb: University of Zagreb.

Kedourie, Elie (1961) Nationalism. Revised edition. Hutchinson \& Company.

Kedourie, Elie (1968) The End of the Ottoman Empire. Journal of Contemporary History, 3(4), 19-28.

Klix.ba (2016) Nije šala: Tri bošnjačka udruženja predlažu Erdogana za Nobelovu nagradu za mir. In Klix.ba [Online, 30 July 2016]. http://www.klix.ba/vijesti/bih/nije-sala-tri-bosnjacka-udruzenjapredlazu-erdogana-za-nobelovu-nagradu-za-mir/160721049 [accessed 15 September 2016].

Kordić, Snježana (2001) Naziv jezika iz znanosti gledan, Knjižerna republika, $57(1-2)$.

Kostovicova, Denisa (2004) Republika Srpska and its Boundaries in Bosnian Serb Geographical Narratives in the Post- Dayton Period. Space and Polity, $8(3), 267-87$.

Lučić, Iva (2009) Stavovi centralnog komiteta saveza komunista Jugoslavije o nacionalnom identitetu bosanskih Muslimana/bošnjaka. Između afirmacije, negacije i konfesionalne artikulacije. In Husnija Kamberović (ed.) Rasprave o nacionalnom identitetu Bošnjaka. Sarajevo.

Matthias, John and Vučković, Vladeta (1987) The Battle of Kosovo. Aquila.

Mažuranić, Matija (2007) A glance into Ottoman Bosnia, or A short journey into that land by a native in 1839-40. Saqi Books.

Mišković, Nataša (2011) Mission, Power, and Violence: Serbia's National Turn. IB Tauris. 
Moaddel, Mansoor (2005) Islamic modernism, nationalism, and fundamentalism: episode and discourse. University of Chicago Press.

Müller, Jan-Werner (2011) European Intellectual History as Contemporary History. Journal of Contemporary History, 46(3), 574-90.

Naumović, Slobodan (1999) Identity creator in identity crisis: Reflections on the politics of Serbian ethnology. Anthropological Journal on European Cultures, 8 (2), 39-128.

Novaković, Stojan (1886) S Morave na Vardar, 26-29 oktobra 1886, putne beleške. Godišnjica Nikole Čpić, XXXII, knj, 13(49), 26-29.

Ozkirimli, Umut (2005) Contemporary debates on nationalism: A critical engagement. Palgrave Macmillan.

Pavlovič, Stevan K (1999) A history of the Balkans: 1804-1945. Longman.

Petrović, Žarko and Reljić, Dušan (2011) Turkish Interests and Involvement in the Western Balkans: A Score-Card. Insight Turkey, 13(3), 159-72.

Pohl, Heinz-Dieter (1996) Serbokroatisch-Rückblick und Ausblick. In I Ohnheiser (ed.) Wechselbeziehungen zwischen slawischen Sprachen, Literaturen und Kulturen in Vergangenheit und Gegenwart. Innsbruck, 205-19.

Rabrenovic, Gordana (1997) The dissolution of Yugoslavia: Ethnicity, nationalism and exclusionary communities. Dialectical anthropology, 22(1), 95101.

Rieff, David (1996) Slaughterhouse: Bosnia and the Failure of the West. Simon and Schuster.

Said, Edward (1979) Orientalism. New York: Vintage, 1994.

Schwoebel, Robert H (1965) Coexistence, Conversion, and the Crusade against the Turks. Studies in the Renaissance, 12, 164-87.

SETA.dc (2009), Address by His Excellency Foreign Minister of Republic of Turkey Ahmet Davutoğlu, Principles of Turkish Foreign Policy. In SETA's website, [Online, 20 June 2011]. Available at: http:/ / setadc.org/index.php?option=com_content\&view=article\&id=202:u nofficial-transcript-of-foreign-minister-ahmed-davutoglusspeech\&catid=58:text\&Itemid=113 [accessed 15 September 2016].

Shotwell, James Thomson (1949). A Balkan mission. Columbia University Press. 
Smith, Anthony D (1983) Theories of Nationalism: Anthony D. Smith. Holmes \& Meier Pub.

Soykut, Mustafa (2001) Image of the "Turk" in Italy: A History of the "other" in Early Modern Europe 1453-1683. Berlin: K. Schwarz.

Stajić, Vasa (1926) Svetozar Miletić and the Liberal Idea among the Jugoslavs. The Slavonic Review, 5(13), 106-13.

Stover, Eric and Peress, Gilles (1998) The Graves: Srebrenica and Vukovar. Scalo Verlag Ac.

Šuica, Marko (2010) Percepcija osmanskog carstva u Srbiji. In Božidar Jezernik (ed.) Imaginarni Turčin, ur. Božidar Jezernik. XX Vek, 285-98.

Sundhaussen, Holm (2008) Istorija Srbije od 19. do 21. veka. Clio Beograd.

Thomas, Paul-Louis (2003) Le serbo-croate (bosniaque, croate, monténégrin, serbe): de l'étude d'une langue à l'identité des langues. Revue des études slaves 74(2), 311-25.

Trgovcevic, Ljubinka (1999) The Kosovo Myth in the First World War. In Projekat Rastko Gracanica-Pec website.

van Dijk, T. A. (1993) Principles of Critical Discourse Analysis. Discourse $\mathcal{E}$ Society, 4(2), 249-83.

Vuletić, Frano (1890) Gramatika bosanskog jezika za srednje škole, Dio I. i II. Sarajevo. 